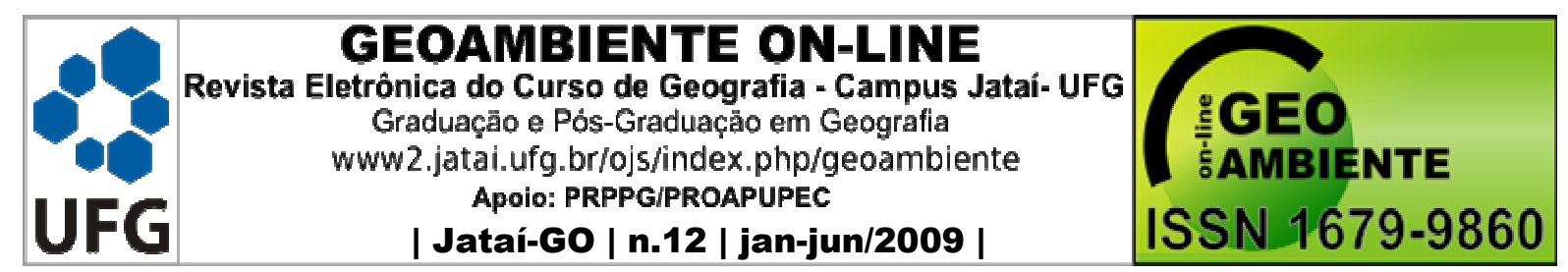

\title{
A POLUIÇÃO URBANA E O IMPACTO NA QUALIDADE DA ÁGUA DO RIO DAS ANTAS - IRATI/PR
}

Aparecido Ribeiro de ANDRADE ${ }^{\mathbf{1}}$, e Ivo Marcelo FELCHAK ${ }^{\mathbf{2}}$

(1 - Professor Assistente do Departamento de Geografia da UNICENTRO, Campus de Irati, PR 153, Km 7, Bairro Eng ${ }^{\circ}$ Gutierrez, CEP 84500-000, Irati - Paraná. Vice-líder do GESTER - Grupo de Estudos e Pesquisa para a Gestão do Território. E-mail: arandrade@irati.unicentro.br, 2 - Licenciado em Geografia pela Universidade Estadual do Centro-Oeste - UNICENTRO, Campus de Irati - Paraná. e Professor do Serviço Social da Indústria - SESI (Irati). E-mail: imfelchak@gmail.com)

\section{Resumo}

O presente trabalho enfoca a questão relacionada a impactos ambientais urbanos, utilizando para isso o exemplo dos impactos causados ao rio das Antas, localizado na área urbana do município de Irati-PR, e contribuinte do rio Imbituvão, fornecedor de água para o consumo dos habitantes da região. Os procedimentos utilizados na referida avaliação centraram-se em trabalhos de campo amparados na bibliografia especializada, que propiciaram uma investigação in loco das condições socioambientais da área de estudo. Os impactos causados pela utilização inapropriada do espaço urbano foram estudados, sendo identificados vários fatores que provocaram a alteração nas características naturais do leito do rio. A intervenção inapropriada, desorganizada e sem critérios de planejamento adequados, intensificaram a deterioração da qualidade da água e o desaparecimento quase total da mata ciliar, responsável pelo equilíbrio geomorfológico do rio. Processos oriundos dessa má ocupação do solo, como erosão das margens, assoreamento do rio e poluição das águas, foram identificados como provável causa da diminuição do volume de água à jusante do rio, além da inexistência da fauna e flora típicas da área. A falta de interesse do poder público na organização e planejamento do uso e ocupação do solo foi identificada como uma causa social e política dos impactos negativos na área estudada.

Palavras-chave: Impactos socioambientais, poluição hídrica urbana, rio das Antas, Irati

Artigo recebido para publicação em 12 de Janeiro de 2009;

Artigo aprovado para publicação em 03de Junho de 2009 


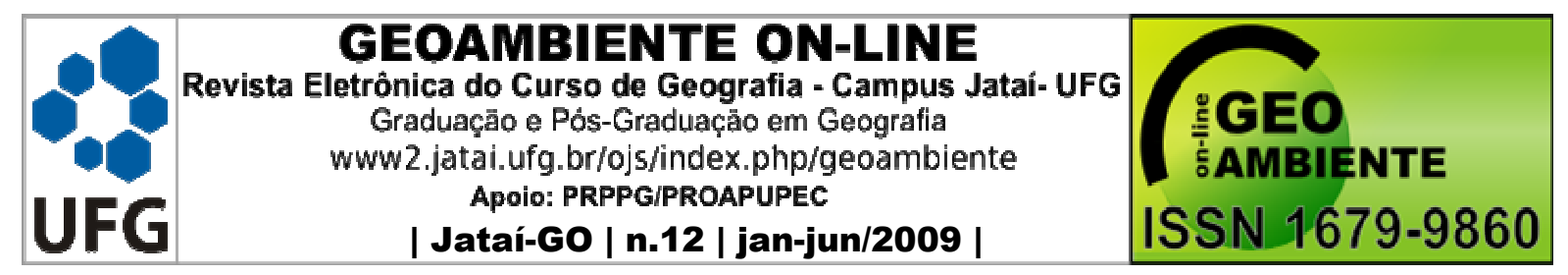

\section{Abstract \\ THE URBAN POLLUTION AND THE IMPACT IN THE QUALITY OF THE WATER OF THE ANTAS RIVER - IRATI/PR}

The present work focuses the subject related to urban environmental impacts, using for that the example of the impacts caused to the Antas river, located in the urban area of the municipal district of Irati-PR, and contributor of the Imbituvão river, supplier of water consumption for the inhabitants of the area. The used procedures it referred evaluation was centered in field works aided in the specialized bibliography that propitiated an investigation in locus of the socioenviromental conditions of the study area. The impacts caused by the inappropriate use of the urban space they were studied, being several identified factors that provoked the alteration in the natural characteristics of the bed of the river. The inappropriate intervention, disorganized and without convenient planning discretion, they intensified to deterioration of the quality of the water and the almost total disappearance of the ciliary forest, responsible for the geomorphologic balance of the river. Processes originating from of that bad land occupation, as erosion of the margins, sedimentation of the river and pollution of the waters, were identified as probable cause of the decrease of the volume of water to the downstream of the river besides the inexistence of the fauna and flora typical of the area. The lack of interest of the public power in the organization and planning of the use and occupation of the land was identified as a social and political cause of the negative impacts in the studied area.

Key-words: socioenviromental impacts, hydric pollution urban, Antas river, Irati

\section{Introdução}

A problemática que envolve a questão ambiental urbana é algo desafiante para pesquisadores de várias áreas do conhecimento, principalmente para a Geografia. Tal perspectiva se deve ao fato de que a amplitude das relações inerentes à sociedade, aliada à complexidade dos ambientes urbanos, compreendidos enquanto sua moradia natural, está totalmente inserida na discussão central da ciência geográfica contemporânea (sociedadenatureza).

A geografia tradicional tratava de descrever o meio, enquanto a geografia crítica defendia que o ser social (homem) e suas relações deveriam ser priorizados (CLAVAL, 2002), então a resposta para estudos que busquem uma maior compreensão, tanto da realidade 


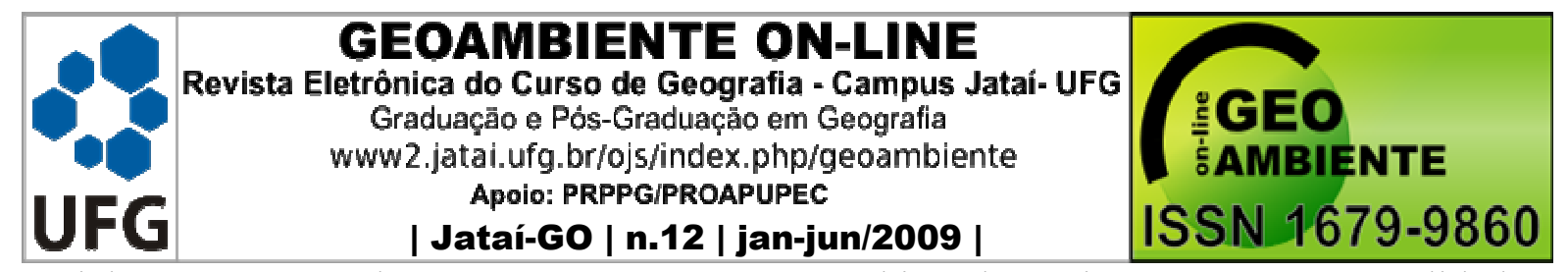

social quanto natural, parece ser a "corrente ambiental", pois tem como centralidade a discussão das relações "sociedade-natureza" ou "sociedade/natureza".

Parecem estarem repetidos os termos entre aspas, mas não é verdade, numa perspectiva fenomenológica mais apurada, são temas ou propostas diferentes. No primeiro caso, separado por hífen, a impressão que se tem é de que o termo é um só, ou seja, a sociedade se insere na natureza e vice-versa. Enquanto no segundo, a barra dá uma conotação de separação, ou pelo menos de relações separadas e que, portanto, devem ser estudadas de forma diferente, buscando uma possível relação integradora. Esta pequena discussão reafirma a dificuldade da definição epistemológica na geografia contemporânea. Qual termo seria mais aconselhável? Qual deles responderia às indagações presentes?

Da mesma forma que as discussões sobre a relação sociedade-natureza se encontram em profundo debate dentro da ciência geográfica (GERARDI \& LOMBARDO, 2004), a temática relacionada aos impactos ambientais urbanos também está sendo profundamente discutida no meio acadêmico, não só por profissionais da geografia, mas pela ciência como um todo, pelo menos os ramos dedicados a compreender os problemas relacionados à dinâmica da produção do espaço e seus efeitos na qualidade de vida. (GUERRA \& CUNHA, 2006).

Essa discussão permeia a definição de espaço geográfico, entendido como local da produção e reprodução de práticas sociais, criando particularidades próprias a uma determinada região. $\mathrm{O}$ ambiente urbano se torna central na temática, pois possui toda a gama de componentes internos e externos que propiciam uma complexidade sem igual. Tanto os pesquisadores voltados à abordagem naturalista, como aqueles dedicados aos estudos sociais ou sociológicos, encontram na cidade um objeto de estudo ideal. "Por espaço vamos entender o meio, o lugar material da possibilidade de eventos, o meio onde a vida é tornada possível" (SANTOS, 1994, p. 41).

O espaço pode assim ser considerado como uma dimensão das relações mais amplas possíveis, a sociedade-natureza enquanto conceito se torna mais importante ainda, principalmente no espaço socialmente construído chamado de "cidade". Esse espaço social está sendo estudado há muito tempo e sua definição pode ser resumida como:

“O espaço social é, primeiramente ou em sua dimensão material e objetiva, um produto da transformação da natureza (do espaço natural: solo, rios, etc.) pelo trabalho social. Palco das relações sociais, o espaço é, portanto, um 


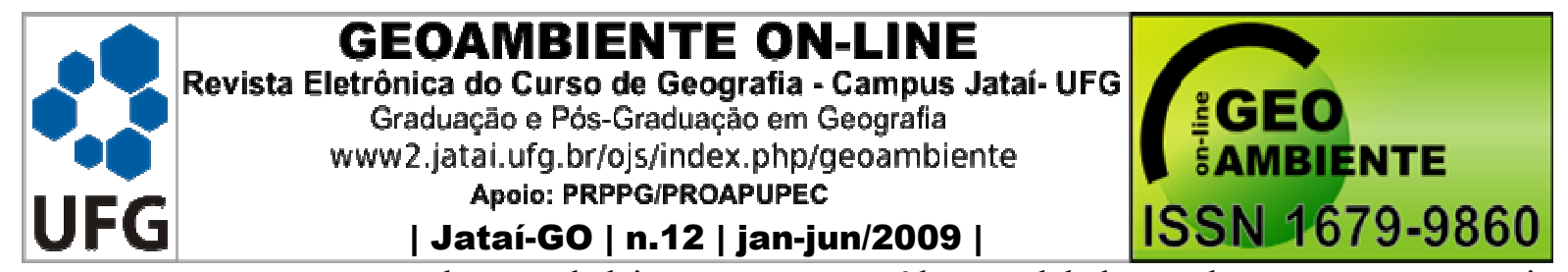

palco verdadeiramente construído, modelado, embora em graus muito variados de intervenção e alteração pelo homem, das mínimas modificações induzidas por uma sociedade de caçadores e coletores (impactos ambientais fracos) até um ambiente construído e altamente artificial como uma grande metrópole contemporânea (fortíssimo impacto sobre o ambiente natural), passando pelas pastagens e pelos campos de cultivo, pelos pequenos assentamentos, etc. Não é um espaço abstrato ou puramente metafórico (acepção usual no domínio do senso comum e em certos discursos sociológicos, a começar por Durkheim), mas um espaço concreto, um espaço geográfico criado nos marcos de uma determinada sociedade" (SOUZA, 1997, p. 22).

O espaço conceituado pelo autor citado não se limita ao ambiente urbano, mas é notório sua identificação com a cidade, pois sua especialidade é a discussão da temática urbana, pelo menos os referenciais encontrados para suas obras sempre estiveram preocupado com tal abordagem. Entretanto, indiferente do pensamento intrínseco à citação, o objetivo é mostrar que os impactos ambientais urbanos, considerando a construção do espaço e a relação sociedade-natureza, é a base da discussão na busca de causas e efeitos dos problemas socioambientais da cidade.

Neste trabalho foi possível conhecer um pouco mais sobre os problemas que afetam o município de Irati, principalmente as questões ligadas à degradação do ambiente e os impactos causados por eles. Tais impactos provocam a alteração das propriedades físicas, químicas e biológicas do ambiente, independente do grau de intervenção da sociedade.

O tema delimitado foi a questão do lixo urbano de forma mais genérica e do esgoto doméstico de forma mais específica, além da sua influência na qualidade da água do rio das Antas, por encontrar-se inserido quase que completamente na área urbana do município de Irati, cruzando por vários bairros, inclusive o centro da cidade.

A degradação em que se encontra o rio das Antas é visível em todo o seu percurso, pois qualquer cidadão percebe suas margens erodidas, leito assoreado, ausência de mata ciliar, lixo depositado às margens do corpo hídrico e despejo de esgoto doméstico.

Com o crescimento urbano desordenado, sem planejamento e com falta de saneamento básico, intensificados a partir da década de 1960, aumentou a degradação ambiental no rio das Antas, local este que até então era utilizado como fonte de alimento, captação de água por moradores lindouros e área de lazer.

A busca por um diagnóstico dos impactos causados pela utilização indevida do solo às margens do rio das Antas, bem como, suas origens, foi a proposta central deste trabalho, 


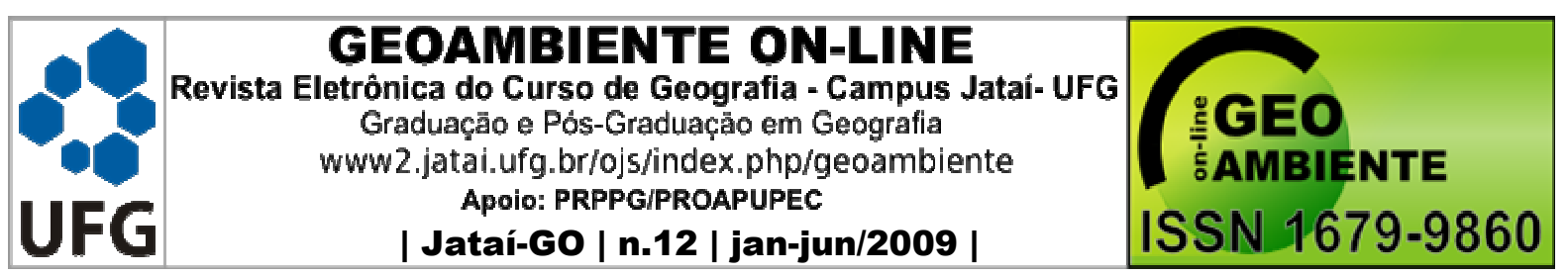

principalmente com relação ao esgoto doméstico, que demonstrou ser um dos principais problemas, vindo a interferir na qualidade de vida da população.

\section{1. caracterização da área de estudo}

O município de Irati está localizado na zona fisiográfica de Irati, uma das onze zonas em que o Paraná se divide. Encontra-se na sub-região dos pinhais, no segundo planalto do Paraná ou planalto de Ponta Grossa, tem como coordenadas geográficas: $-25^{\circ} 25^{\prime} 05^{\prime \prime}$ a $25^{\circ} 32^{\prime} 38^{\prime \prime}$ de latitude Sul e $-50^{\circ} 32^{\prime} 42^{\prime \prime}$ a $-50^{\circ} 42^{\prime} 05^{\prime}$ ' de longitude Oeste. Situa-se à distância de $138 \mathrm{~km}$ em linha reta na direção $88^{\circ} 21^{\prime}$ 'Oeste e a $150,34 \mathrm{~km}$ pela BR 277 , de Curitiba, capital do Estado, fazendo divisa com os municípios de Imbituva, Prudentópolis, Inácio Martins, Rio Azul, Rebouças e Fernandes Pinheiro, Figura 1. Situa-se na região centro-sul do estado, de clima temperado $(\mathrm{Cfb})$, com temperatura desde o mínimo de $-5{ }^{\circ} \mathrm{C}$, até o máximo de $38{ }^{\circ} \mathrm{C}$. As geadas são freqüentes e as chuvas caem com mais intensidade de setembro a fevereiro (IPARDES, 2006).

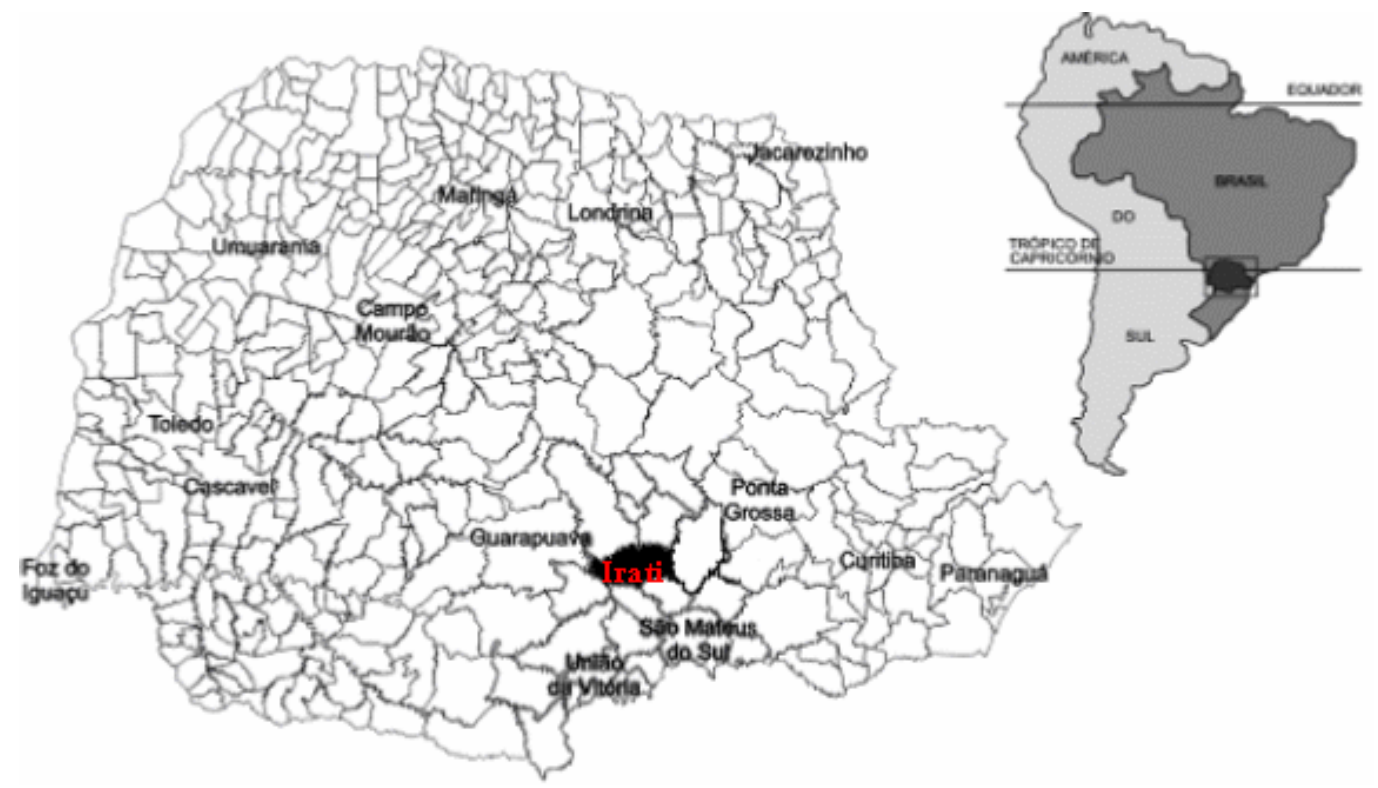

Figura 1 - Localização do município de Irati - sem escala

Entre os rios que banham o município de Irati, destacam-se o rio dos Patos, rio Caratuva, rio das Antas, rio Preto, rio Riozinho, rio Cachoeira, rio Ponte Alta, rio Água Quente e rio Taquari. Seus cursos dirigem-se para as bacias dos rios: Tibagi, Ivai e Iguaçu, todos pertencentes à bacia do rio Paraná.

O território do município é bastante acidentado, sendo dois terços do município classificados como montanhosos. Geologicamente, a região de Irati formou-se no permiano 


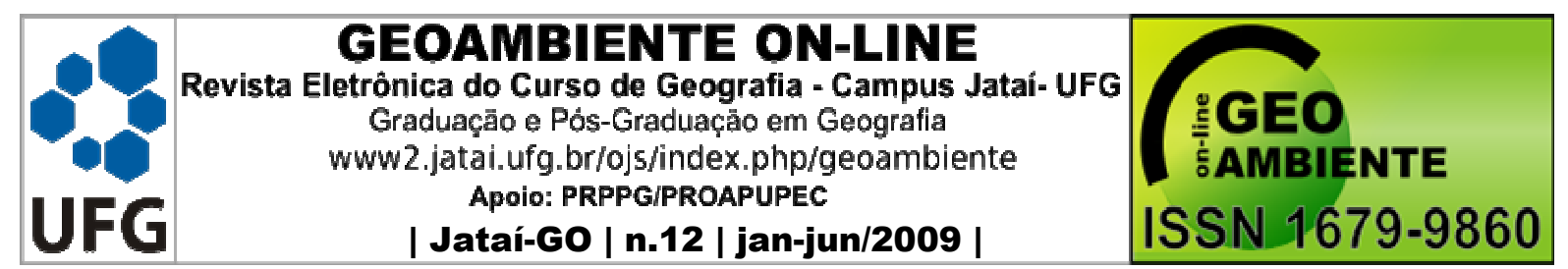

carbonífero, com topografia ondulada e acidentada. Os solos são acinzentados/vermelhos disseminados ao norte e castanhos ao sul da região.

A Formação Irati é uma jazida de folhelho piro-betuminoso que inicia em São Paulo e vai até o Rio Grande do Sul, são rochas sedimentares de cor que varia do cinza-escuro ao preto. Também são encontrados com freqüência trilobites, ostras e estrelas do mar, confirmando que esta região foi fundo de mar. Estas rochas argilosas folheadas, denominadas folhelhos, são ricas em fósseis do Mesosaurus brasiliensis MacGregor, réptil de grande porte, que atraíram o interesse geral ao encontrarem fósseis quando da retilinização do rio das Antas nas proximidades da Avenida Vicente Machado em 1970 (MINEROPAR, 2006).

O município nasceu em 1907, no auge do ciclo econômico da erva mate que perdurou até 1930, quando a exploração de pinho ultrapassou a de erva mate beneficiando Irati como nenhum outro município da região (ORREDA, 1972 e 1974)

Segundo o último censo demográfico, Irati tem um total de 52.352 habitantes, sendo $39.306(75,10 \%)$ na zona urbana e $13.046(24,90 \%)$ na zona rural. A população economicamente ativa totaliza 18.381 na zona urbana e 6.546 na zona rural. Segundo os aspectos sócio-econômicos, 57,89 \% desenvolve atividades no setor de serviços, 26,18 \% no setor industrial e 15,93 \% no setor agropecuário (IBGE, 2000 apud IPARDES, 2006).

O maior desenvolvimento da cidade de Irati teve como ponto principal a chegada dos trilhos da estrada de ferro São Paulo/Rio Grande. Trilhos estes que acompanhavam os vales fluviais levando ao surgimento de casas de comércio e habitações próximos às ferrovias, habitações estas construídas normalmente no leito maior excepcional dos rios.

O rio das Antas é um rio de segunda ordem e um dos principais corpos hídricos do município de Irati e sua maior extensão percorre a área urbana do município, nasce na serra de Nhapindazal (área rural) e depois de percorrido aproximadamente 1,5 km entra no perímetro urbano pelo bairro Vila São João. Em seu percurso, passando por vários bairros, inclusive o centro da cidade, recebe vários tributários, até sair do perímetro urbano quando passa sob a ponte na BR 277 (Figura 2). Percorre mais alguns quilômetros até sua foz, desaguando no rio Imbituvão, rio este que pertence à bacia do Tibagi. 


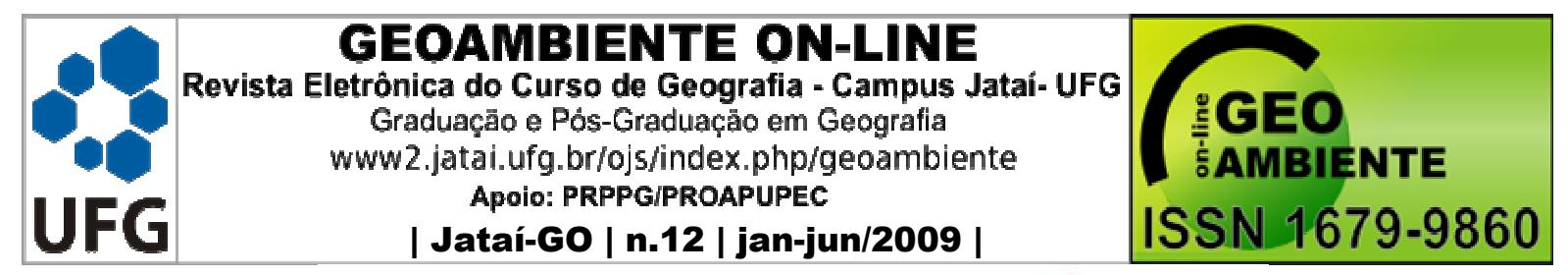

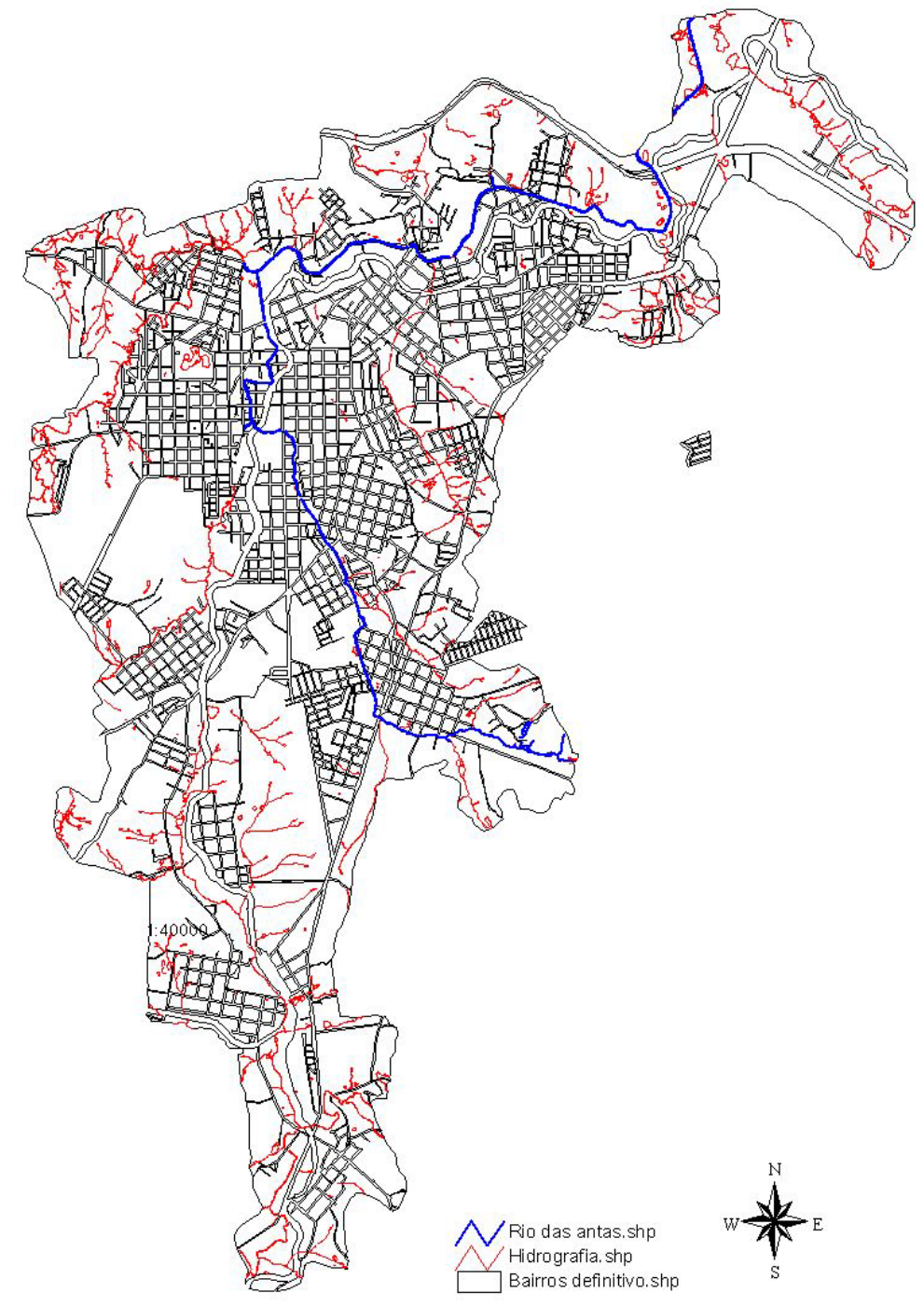

Figura 2 - Rio das Antas no perímetro urbano de Irati Fonte: Prefeitura Municipal de Irati (sem escala)

Com o crescimento urbano desordenado ao logo da bacia do rio das Antas, sem planejamento e falta de saneamento básico a partir da década de 1960, iniciou-se a degradação do rio das Antas, fazendo com que se perdessem as relações culturais da população com o seu rio, que até então era utilizado como fonte de água (alimentação e lazer).

\section{Procedimentos Metodológicos}

A escolha de uma bacia hidrográfica como objeto de estudo, se justifica por ser a bacia de drenagem um sistema aberto e a principal categoria de análise dos problemas ambientais, por estarem integradas pelos divisores topográficos, encostas, topos e fundos de vales, canais, corpos de água subterrânea, sistemas de drenagem urbanos e áreas irrigadas, formando uma 


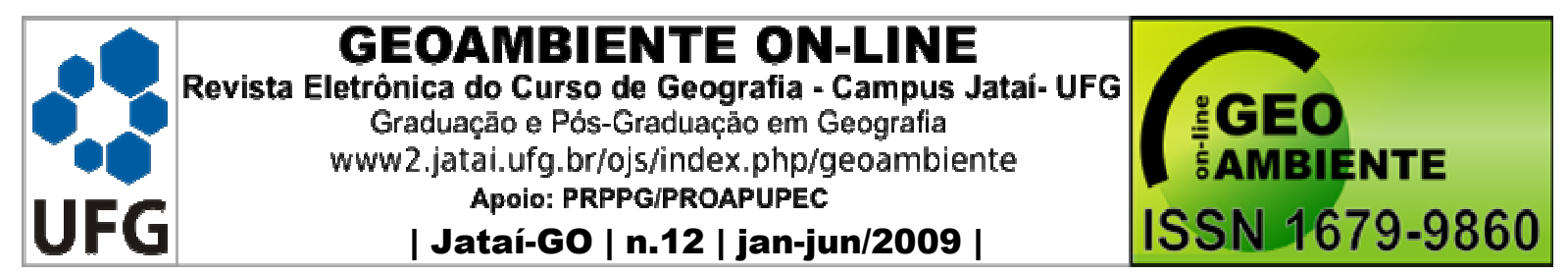

rede onde cada uma delas drena águas, materiais sólidos e dissolvidos para uma saída comum ou ponto terminal, que pode ser outro rio de hierarquia igual ou superior, lago, reservatório, ou oceano.

Entretanto, os aspectos estudados neste trabalho não tencionam diagnosticar a bacia hidrográfica como um todo, mas somente a parte urbana do rio das Antas e o uso do solo em suas margens, objetivando principalmente o reconhecimento de possíveis alterações na paisagem fluvial, fator que pode ser prejudicial às condições hídricas do rio.

As mudanças ocorridas num sistema fluvial podem ter causas naturais, mas normalmente o que se encontra é uma aceleração nos processos modificadores e de desequilíbrio da paisagem, causados principalmente pelas atividades inerentes à realidade urbana. O estudo compreendeu etapas de trabalho diferenciadas, desenvolvidas seqüencialmente, buscando adequar os levantamentos realizados em campo aos objetivos propostos.

Inicialmente, foram realizadas incursões ao rio das Antas desde a Vila São João, onde o rio adentra o perímetro urbano, percorrendo toda sua extensão até chegar à ponte na BR277, ponto a partir do qual o rio passa a percorrer área rural até sua foz no rio Imbituvão. Também foi estendido este procedimento para os principais afluentes, no intuito de elaborar um diagnóstico através de fotografias e observações dos principais problemas que ocorrem na bacia do rio das Antas.

O lixo urbano produzido por moradores das margens do rio não foi identificado de forma clara, apesar de existirem relatos da população local sobre a falta de consciência de alguns citadinos, depositando material não degradável próximo das margens do rio. $\mathrm{O}$ possível impacto causado por essa ação não foi notado em nenhum dos levantamentos efetuados, propiciando falta de dados para possíveis investigações sobre o impacto causado.

A identificação dos impactos negativos causados pela ocupação inapropriada das margens do rio, ficou centrada no diagnóstico da qualidade da água, pois a escassez de um dos principais recursos naturais no mundo é o maior limitador da vida na Terra, limitando o desenvolvimento da agricultura, o crescimento da indústria e da sociedade como um todo.

Segundo Drew (2002), o que inibia a expansão da agricultura e o povoamento de vastas regiões era a insuficiência de água. Os recursos hídricos influenciam a localização de 


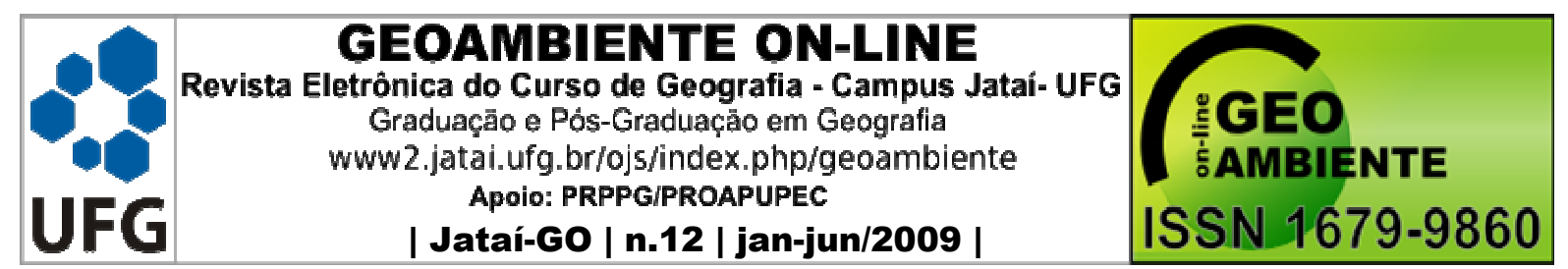

certas indústrias, como a geração de energia. Antigamente, o estabelecimento de povoações estava em relação estreita com a localização de rios e fontes.

Por instinto e por necessidade, em todos os tempos e lugares, o homem tem firmado o seu domicílio e as coletividades, instalando suas sedes onde há segurança de água fácil e abundante, junto a nascentes, à margem de rios ou de lagos, à beira-mar ou onde os lençóis aqüíferos do subsolo sejam certos e acessíveis (PUPPI, 1981).

No Brasil, devido à abundância de rios, a população se deixa levar pela sensação de que os recursos hídricos são inesgotáveis, sem levar em conta que todos os dias são despejadas quantidades expressivas de resíduos nos corpos hídricos do território, além dos processos erosivos que levam à conseqüente diminuição no volume de água nos corpos hídricos.

$\mathrm{Na}$ maioria das cidades brasileiras, o processo de urbanização deu-se ao longo dos seus rios, trazendo conseqüências depreciativas não apenas aos recursos hídricos propriamente ditos, mas também na qualidade do ar, do solo, da fauna e da flora (FENDRICH e OLIYNIK, 2002).

Tal referencial propicia credibilidade às afirmações dos moradores das margens do rio das Antas, levando o pesquisador a deduzir que a falta de consciência ambiental da população local deva estar influenciando na degradação das margens do rio, mas a falta de dados empíricos que comprovem tais testemunhos levou a presente pesquisa a abandonar a investigação da influência do lixo urbano na qualidade da água do referido rio.

A próxima etapa de trabalho foi o mapeamento da bacia do rio das Antas no perímetro urbano, utilizando mapas e cartas da base de dados cartográficos da Prefeitura Municipal de Irati.

Verificou-se a necessidade de análises de laboratório de amostras de água, após os trabalhos de campo, onde foi observada a presença de esgoto doméstico liberado in natura diretamente no corpo hídrico, bem como, a constatação de bioindicadores de poluição, como a presença de algas e do odor típico de bactérias consumidoras que causam a eutrofização do corpo hídrico. A partir deste indicativo foram realizadas coletas, a fim de quantificar o grau de contaminação do rio das Antas, especialmente quanto à presença de esgoto doméstico. 


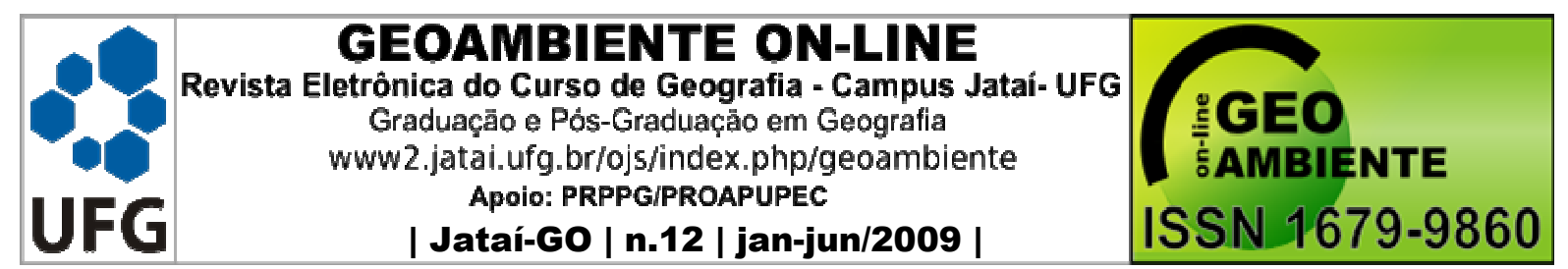

Após o mapeamento da área de estudo, foram selecionados os locais de coleta das amostras de água, visando obter um diagnóstico mais detalhado da qualidade da água do rio das Antas. Tendo sido eleito cinco pontos de coleta:

1. Vila São João próximo a nascente a 491,89 metros da entrada do Colégio Florestal nas coordenadas $25^{\circ} 29^{\prime} 58.78^{\prime \prime} \mathrm{S}$ e $50^{\circ} 38^{\prime} 36.82^{\prime \prime} \mathrm{W}$ altitude de $863 \mathrm{~m}$;

2. Ponte a 197,85 metros da Fábrica de fósforo nas coordenadas $25^{\circ} 28^{\prime} 25.82^{\prime}$ S e 50³9’34.50”W altitude de 820 metros, após a confluência com o arroio da Lagoa;

3. "Pinguela" de ligação do parque ambiental com o bairro Pedreira a 207,69 metros da confluência com o córrego do Caratuva coordenadas 25²7’44.09”'S e 50³9’27.36”'W altitude de 816 metros;

4. Ponte de acesso a propriedade Dallegrave no Centro de Irati 225,47 metros após a “pinguela" de ligação para o Morro da Santa coordenadas $25^{\circ} 27^{\prime} 43.84$ ”S e $50^{\circ} 38^{\prime} 32.05^{\prime} \mathrm{W}$ altitude de 813 metros;

5. Sob a ponte da BR 277 termino do perímetro urbano coordenadas $25^{\circ} 27^{\prime} 19.44$ ”S e $50^{\circ} 37^{\prime} 30.68^{\prime \prime} \mathrm{W}$ altitude de 809 metros.

Os pontos de coleta foram selecionados com o objetivo de demonstrar a variação da qualidade da água, desde o limite da área urbana com a rural, até a parte mais central da cidade. Desta maneira, os pontos 1 e 5 se encontram no limite da área urbana, sendo que o primeiro está a montante do rio e o último a jusante. O ponto 2 está localizado na parte central da cidade. Já os pontos 3 e 4 se localizam em regiões mais periféricas, Figura 03. 


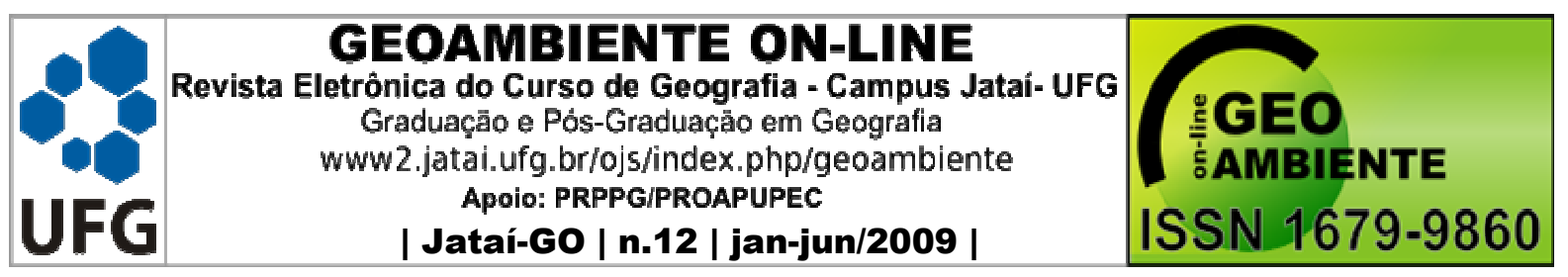

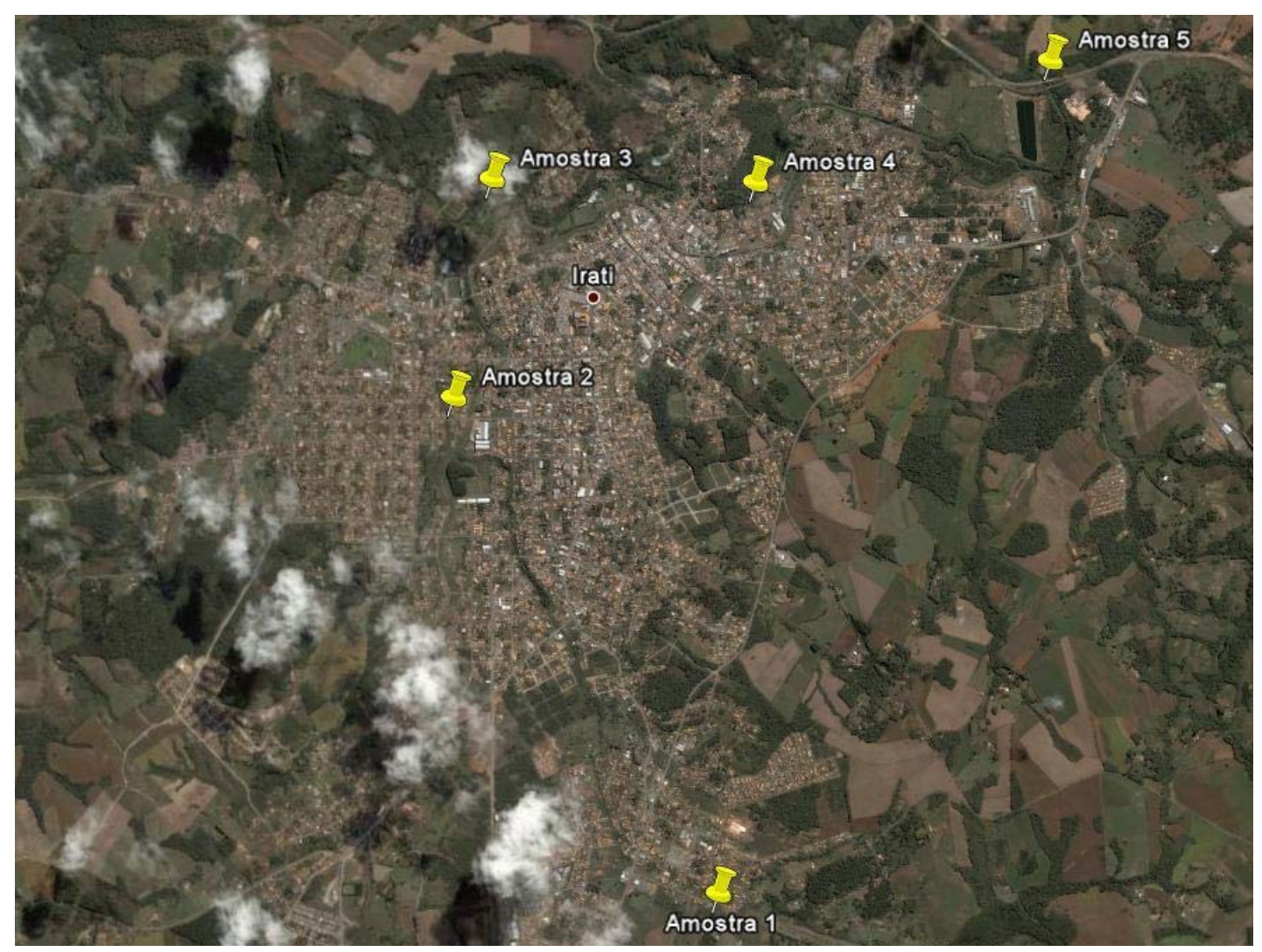

Figura 03 - Localização dos pontos de coleta das amostras de água - Fonte: Google Earth acessado em 03/12/2008

Tal procedimento foi adotado a partir da concentração de atividades urbanas, principalmente com relação à densidade de edificações. Entretanto, buscou-se também coletar amostras da água após a ocorrência da confluência do rio principal com alguns de seus principais afluentes. Os pontos 2, 3 e 4 estão localizados logo após alguns deles. Desta maneira, pretendeu-se enfatizar a diferenciação da qualidade da água desde sua nascente (ponto 1) até sua foz (ponto 5), passando por realidades distintas de uso e ocupação do solo e também de contribuições dos rios tributários.

A contribuição dos afluentes na qualidade da água do rio das Antas é mais notória nos pontos 2, 3 e 4, pois estão imediatamente após as confluências, já o ponto 5 possibilita a observação do acumulo de todas as modificações ocorridas no decorrer do rio. Ressalta-se que o ponto 2, além de representar a realidade oriunda dos primeiros afluentes também está totalmente inserido na área urbana central, inclusive com a presença de uma indústria de produção de fósforos a poucos metros de distância da sua margem. 


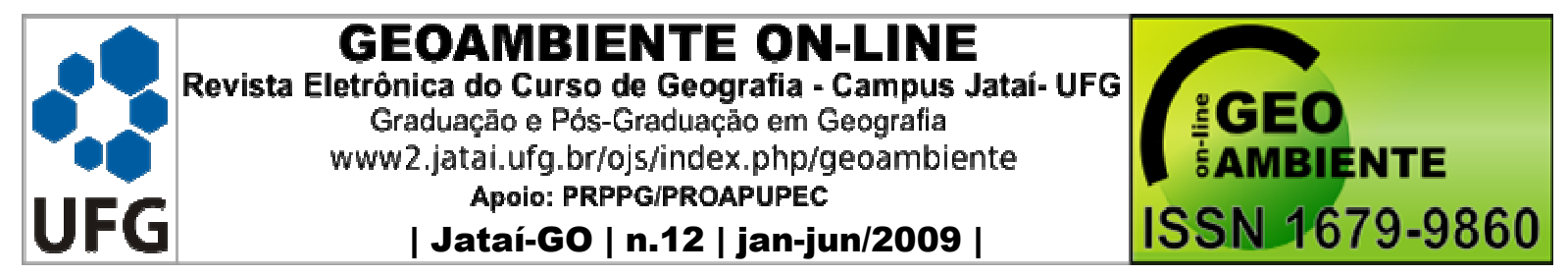

\section{Poluição Urbana}

Ao se tentar conceituar poluição urbana é imprescindível definir um de seus principais causadores: o lixo urbano.

Conforme o Dicionário Aurélio de língua portuguesa "lixo é tudo aquilo que não se quer e que se joga fora; coisas inúteis, velhas e sem valor".

Já para a ABNT - Associação Brasileira de Normas Técnicas NBR 10.004 define lixo como "restos das atividades humanas, considerados pelos geradores como inúteis, indesejáveis ou descartáveis, podendo-se apresentar no estado sólido, semi-sólido (entendem-se como substâncias ou produtos semi-sólidos todos aqueles com teor de unidade inferior a 85\%) ou líquido (válido apenas para resíduos industriais perigosos), desde que não seja passivel de tratamento convencional".

Normalmente os pesquisadores, ao efetuarem trabalhos sobre resíduos sólidos, se utilizam indistintamente dos termos "lixo" e "resíduos sólidos”. Entretanto, resíduo sólido ou simplesmente lixo é todo material sólido ou semi-sólido indesejável e que necessita ser removido por ter sido considerado inútil por quem o descarta, em qualquer recipiente destinado a este ato.

O lixo urbano pode ser classificado de várias maneiras, mas as duas que mais interessam são quanto aos riscos potenciais de contaminação do meio ambiente e quanto à natureza e origem. Não se pode deixar de lado também os efluentes que são dejetos líquidos ou gasosos, emitidos por indústrias, aterros ou residências. Os efluentes necessitam de tratamento especial antes de serem lançados nos rios, no mar, no solo ou no ar.

A origem é o principal elemento para a caracterização dos resíduos sólidos. Segundo este critério, os diferentes tipos de lixo podem ser agrupados em cinco classes, a saber: Lixo Doméstico ou Residencial; Lixo Comercial; Lixo Público; Lixo Domiciliar Especial; e Lixo de Fontes Especiais (NBR 12.808 da ABNT apud MONTEIRO, 2001).

Existem vários problemas decorrentes do lixo, mas a poluição da água é o principal, pois indica que um ou mais de seus usos foram prejudicados, podendo atingir a sociedade humana de forma direta, pois ela é usada por esta como alimento, para tomar banho, para lavar roupas e utensílios, além de ser fonte principal para dessedentação dos animais domésticos. Além disso, abastece as cidades, sendo também utilizada nas indústrias e na irrigação de plantações. Por isso, a água deve ter aspecto limpo, pureza de gosto e estar isenta 


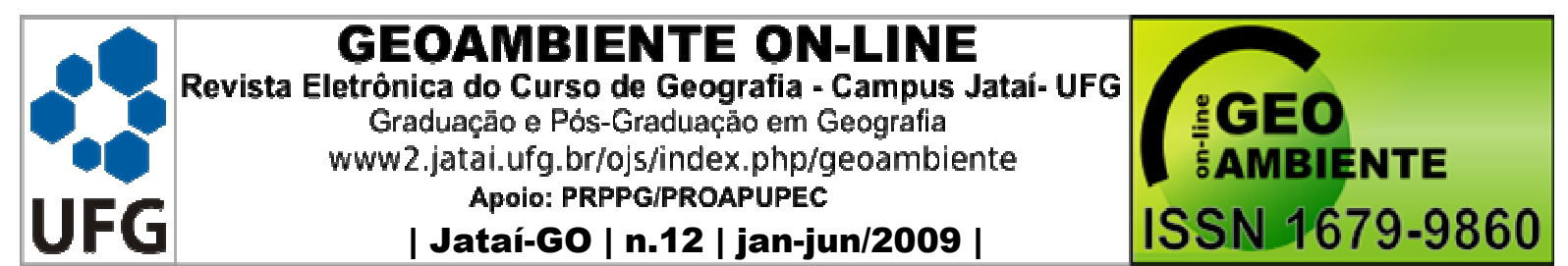

de microorganismos patogênicos, o que é conseguido através do seu tratamento, desde da retirada dos rios até a chegada nas residências urbanas ou rurais. A água de um rio é considerada de boa qualidade quando apresenta menos de mil coliformes fecais e menos de dez microorganismos patogênicos por litro (como aqueles causadores de verminoses, cólera, esquistossomose, febre tifóide, hepatite, leptospirose, poliomielite etc.). Portanto, para a água se manter nessas condições, deve-se evitar sua contaminação por resíduos, sejam eles agrícolas (de natureza química ou orgânica), esgotos, resíduos industriais, lixo ou sedimentos vindos da erosão.

Os resíduos gerados pelas indústrias, cidades e atividades agrícolas são sólidos ou líquidos, tendo um potencial de poluição muito grande. Os resíduos gerados pelas cidades, como lixo, entulhos e produtos tóxicos são carreados para os rios com a ajuda das chuvas. Os resíduos líquidos carregam poluentes orgânicos (que são mais fáceis de ser controlado do que os inorgânicos, quando em pequena quantidade). As indústrias produzem grande quantidade de resíduos em seus processos, sendo uma parte retida pelas instalações de tratamento da própria indústria, que retêm tanto resíduos sólidos quanto líquidos, e a outra parte despejada no ambiente. No processo de tratamento dos resíduos também é produzido outro resíduo chamado "chorume", líquido que precisa novamente de tratamento e controle. As cidades podem ser ainda poluídas pelas enxurradas, pelo lixo e pelo esgoto (GUERRA e CUNHA, 2000).

Enfim, a poluição das águas pode aparecer de vários modos, incluindo a poluição térmica, que é a descarga de efluentes a altas temperaturas, poluição física, que é a descarga de material em suspensão, poluição biológica, que é a descarga de bactérias patogênicas e vírus, e poluição química, que pode ocorrer por deficiência de oxigênio, toxidez e eutrofização.

A poluição das águas, de forma constante e descontrolada, propicia a ocorrência de uma explosão de bactérias decompositoras que consomem oxigênio, contribuindo ainda para diminuir a concentração do mesmo na água, produzindo sulfeto de hidrogênio, um gás de cheiro muito forte que, em grandes quantidades, é tóxico. Isso também afetaria as formas superiores de vida animal e vegetal, que utilizam o oxigênio na respiração, além das bactérias aeróbicas, que seriam impedidas de decompor a matéria orgânica sem deixar odores nocivos através do consumo de oxigênio. 


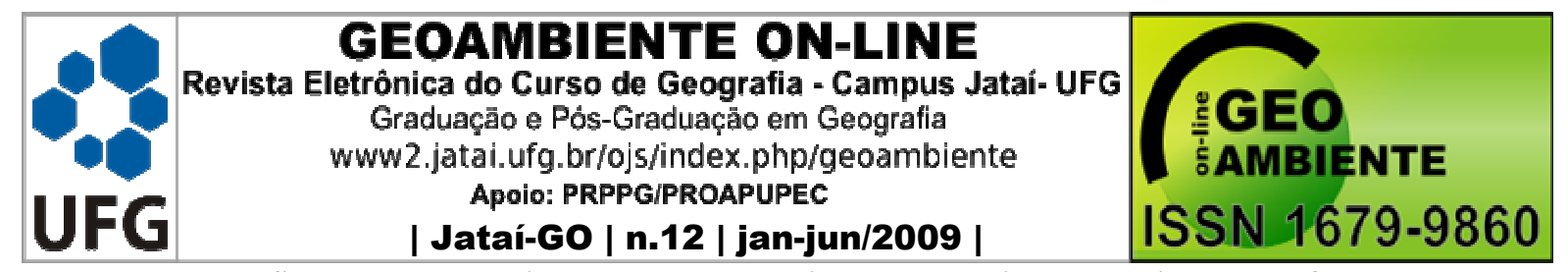

A eutrofização é causada por processos de erosão e decomposição que fazem aumentar o conteúdo de nutrientes, aumentando a produtividade biológica, permitindo periódicas proliferações de algas, que tornam a água turva e com isso podem causar deficiência de oxigênio pelo seu apodrecimento, aumentando sua toxidez para os organismos que nela vivem (como os peixes, que aparecem mortos junto a espumas tóxicas).

O primeiro indicador recomendado para evidenciar contaminação num corpo d'água é a determinação do grupo de bactérias denominadas como coliformes fecais, abundantes em fezes humanas e de animais de sangue quente. São exemplos as bactérias da espécie Escherichia coli e as do grupo dos Enterococcus. Para serem consideradas potáveis (próprias para consumo humano), as águas não devem conter microorganismos patogênicos (causadores de doenças), como essas bactérias (BRANCO, 1993).

Dessa forma, fica evidente que a definição de lixo urbano está totalmente associada ao termo poluição urbana, que por sua vez, apresenta impactos negativos na qualidade da água dos rios urbanos, como é o caso aqui estudado.

Entretanto, as definições aqui utilizadas para poluição urbana, principalmente sua associação ao conceito de lixo urbano é simplesmente um recorte necessário para subsidiar o presente estudo, não esgotando por si só a discussão inerente à conceituação de poluição urbana de forma mais genérica. Tal temática se mostra ampliada no leque das discussões socioambientais ao propor estudos e diagnósticos voltados ao impacto das atividades sociais no meio ambiente.

Nessa perspectiva a poluição urbana é causadora de um dano ambiental significativo, pois a legislação considera dano ambiental qualquer lesão ao meio ambiente causada por ação de pessoa, seja ela física ou jurídica, de direito público ou privado, resultando na degradação da qualidade ambiental. A Lei $n^{0}$ 6938/81 (Política Nacional do Meio Ambiente), traz conceitos de degradação da qualidade ambiental, poluição, poluidor e recursos ambientais. Esta lei traz em seu art. $3^{\circ}$, inciso III, alínea "e" um interessante preceito, definindo que o lançamento de matérias ou energia em desacordo com os padrões ambientais estabelecidos é considerado poluição ou degradação ambiental (ARAÚJO, 2006).

A poluição urbana pode ser considerada como um dano ambiental em sua forma mais ampla, pois todos os aspectos ligados à modificação do meio natural podem vir a causar a degradação das condições ambientais originais, resultando, na maioria das vezes, em aspectos 


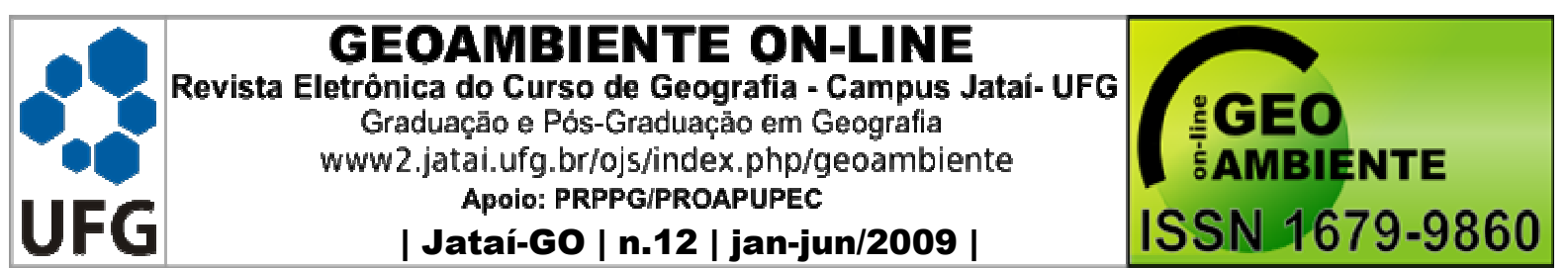

negativos na utilização dos recursos naturais, tendo a água como um dos principais recursos a ser utilizado e normalmente afetado por toda esta modificação do meio.

Por tudo que foi apresentado, pode-se deduzir que o esgoto doméstico é um elemento considerado poluidor e no caso das cidades, está inserido dentro do conceito de poluição urbana. A destinação incorreta deste tipo de poluição normalmente causa degradação ao ambiente e a forma mais eficaz de identificar o nível desta degradação é a investigação da qualidade da água do(s) rio(s) de uma determinada área.

\section{Resultados e Discussão}

A definição de "lixo" como foi visto, engloba todo e qualquer resíduo sólido ou líquido descartado após a utilização de um determinado recurso. Desta forma, apesar do trabalho se propor a investigar outros impactos causados na dinâmica fluvial do rio das Antas, entende-se que o "esgoto doméstico" deva ser considerado exemplo de lixo urbano e mais ainda, inserido na categoria de poluição urbana.

Em princípio, o objetivo do trabalho era uma análise das condições atuais do rio das Antas e sua bacia, tendo como base os aspectos visuais da degradação ocasionada pelo lixo urbano, o que no decorrer do trabalho se mostrou pouco impactante, devido à pouca quantidade de resíduos sólidos encontrados, conforme mostra a Figura 04.

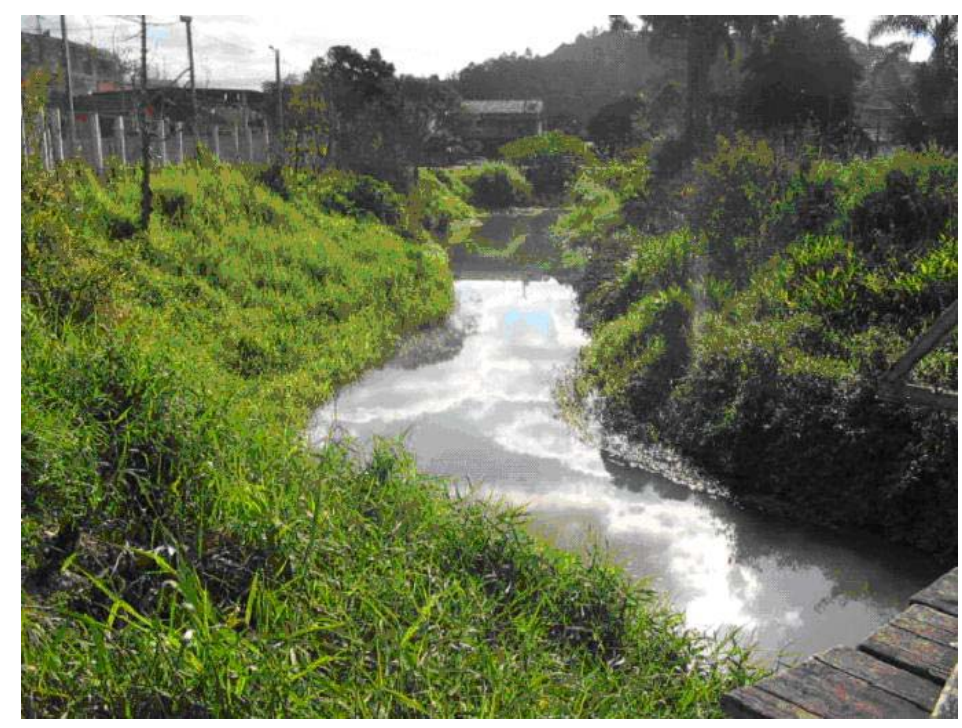

Figura 04 - Ponte próxima à subida do Morro da Santa (Centro)

A Figura 4 busca exemplificar a ausência de lixo urbano às margens do rio das Antas, mas demonstra também cercas, rede elétrica e residências bem próximas às margens do rio, 


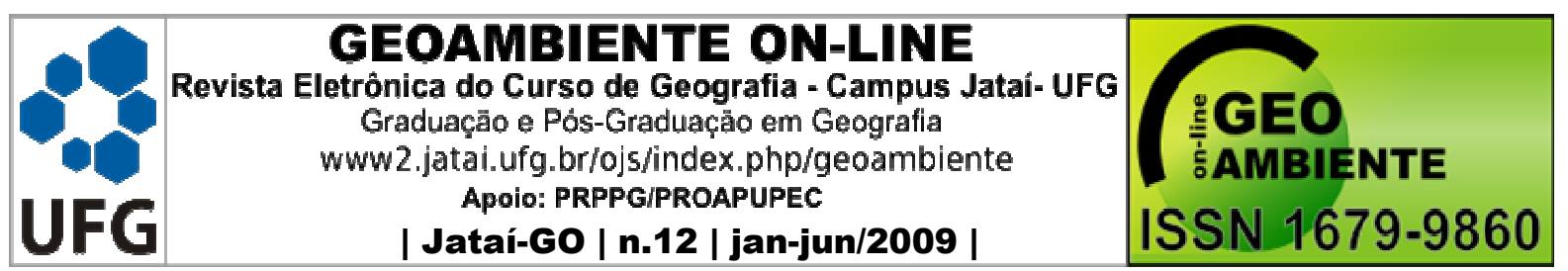

estando totalmente fora dos padrões de conservação considerados ideais, pois essas áreas ocupadas deveriam ser todas florestadas com mata ciliar, sem nenhum tipo de ocupação urbana. Apesar de não apresentar poluição através de resíduos sólidos depositados em suas margens, nota-se que existe pouca vegetação arbórea, com a predominância de espécies arbustivas e muitas gramíneas, recobrimento vegetal pouco significativo na manutenção das condições fluviais do rio.

Com a revisão bibliográfica e trabalhos de campo foram constatados outros problemas, decorrentes de uma ocupação desordenada do meio urbano, como:

a) inexistência de mata ciliar decorrente da ocupação do fundo dos vales, Figura 05;

b) Aceleração do processo de sedimentação proveniente do escoamento das águas superficiais carreando sedimentos das encostas desnudas, Figura 06;

c) assoreamento das margens desprovidas da mata ciliar e pela interferência no leito do rio através da retilinização do canal fluvial em vários pontos da cidade, Figura 07, onde após longos trechos em linha reta há o estrangulamento do canal com curvas de $90^{\circ}$ levando a formação de ilhas fluviais, Figura 08;

d) Acumulação de matéria orgânica proveniente da falta de saneamento, Figura 09; e

e) tratamento incorreto de resíduo industrial causando eutrofização do corpo hídrico e proliferação de agentes patogênicos, Figura 10.

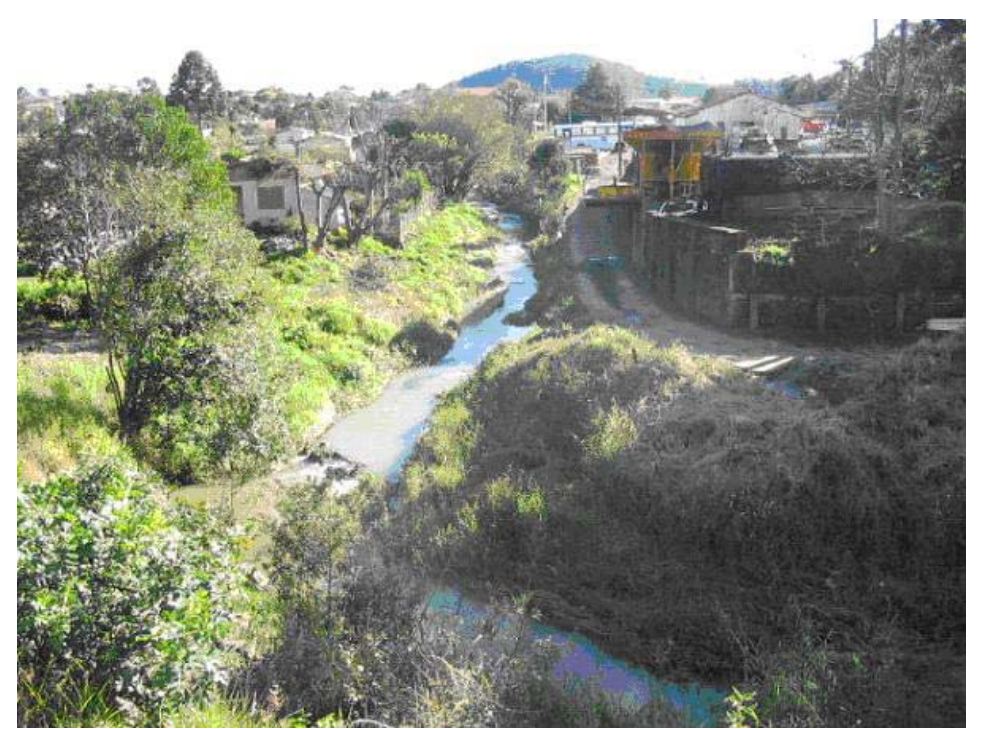

Figura 05 - Ocupação desordenada no bairro Rio Bonito 


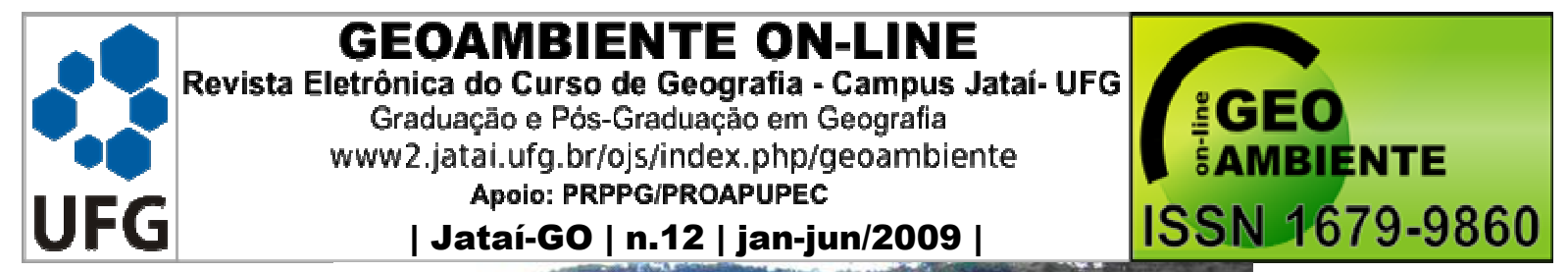

Figura 06 - Formação de área de sedimentação próximo ao Parque Ambiental

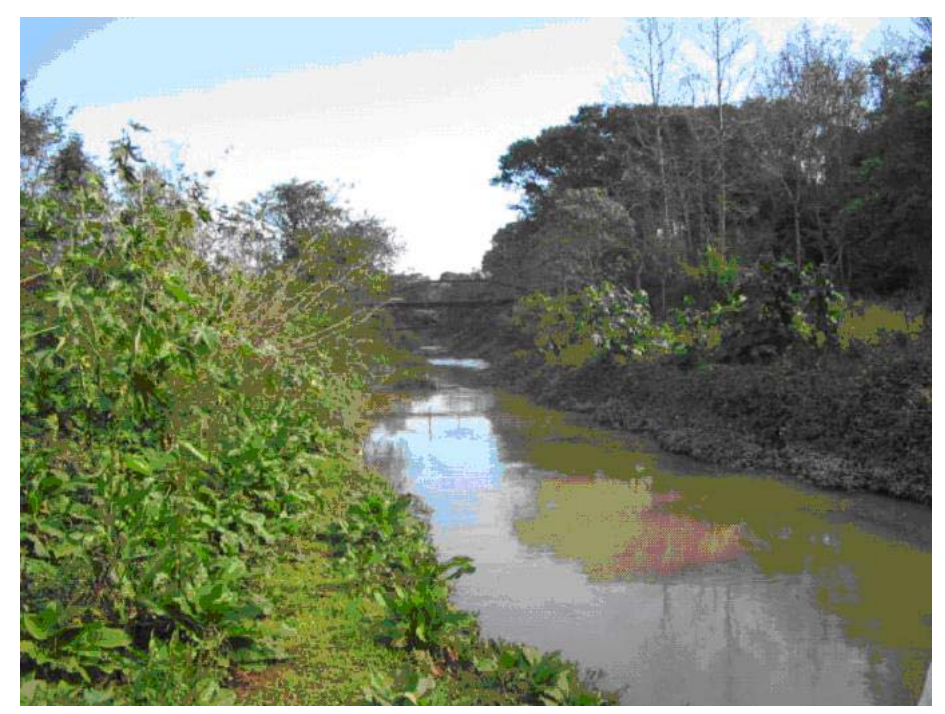

Figura 07 - Parque Ambiental, um dos pontos retilinizados e assoreados.

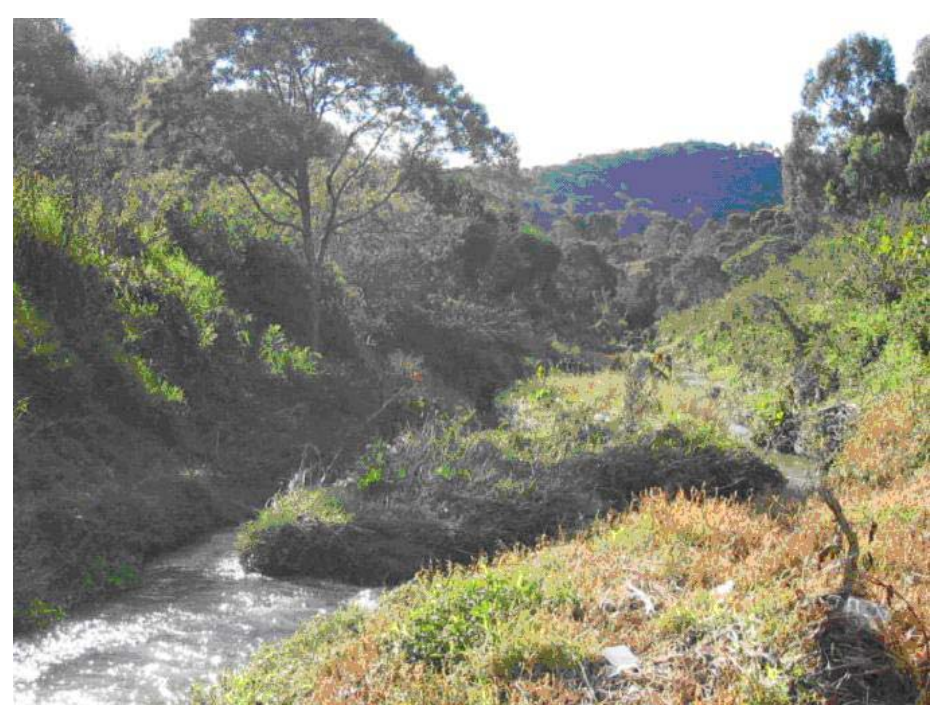

Figura 08 - Ilha fluvial atrás do Irati Sport Clube 


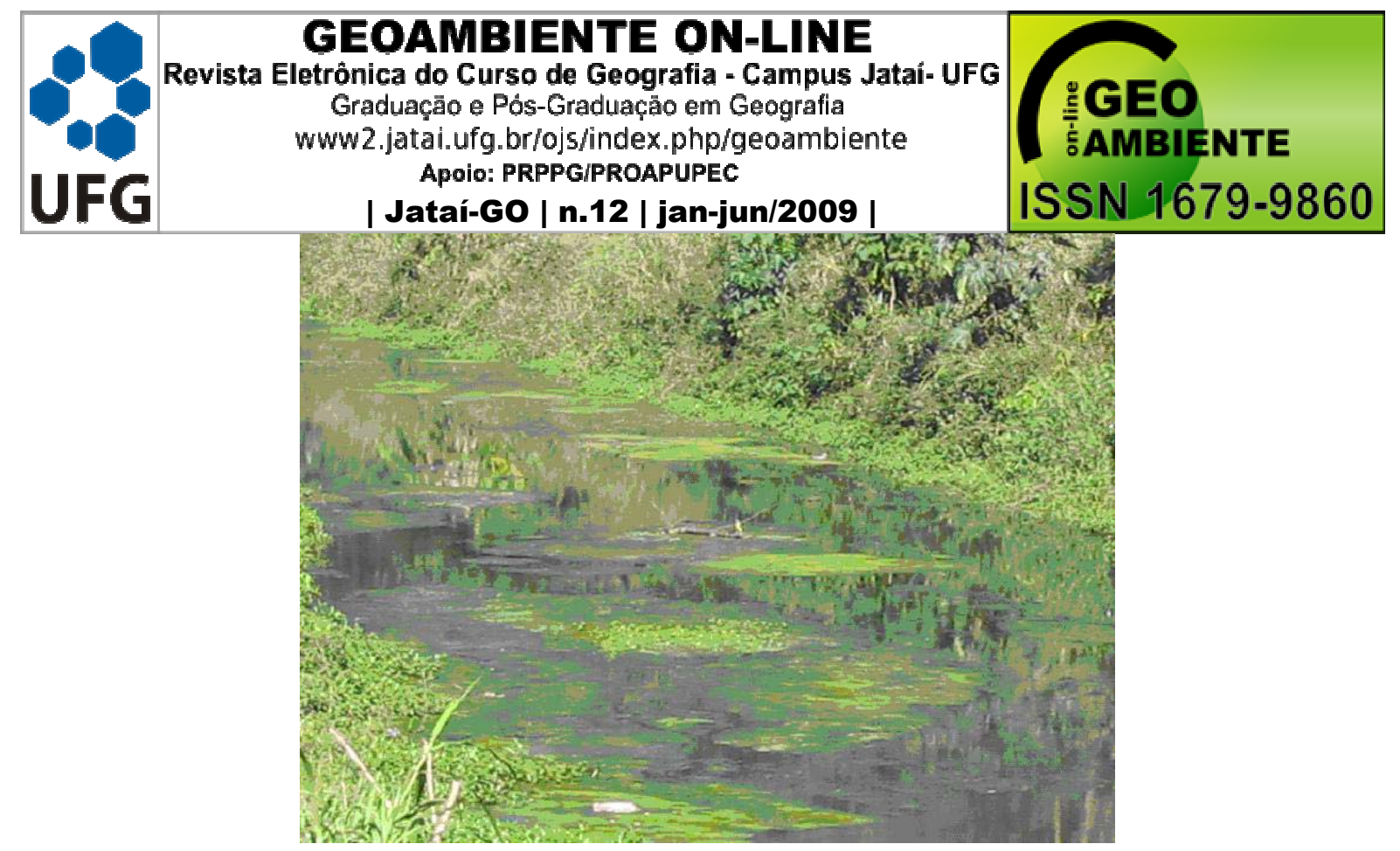

Figura 09 - Acumulação de algas provenientes de resíduos orgânicos

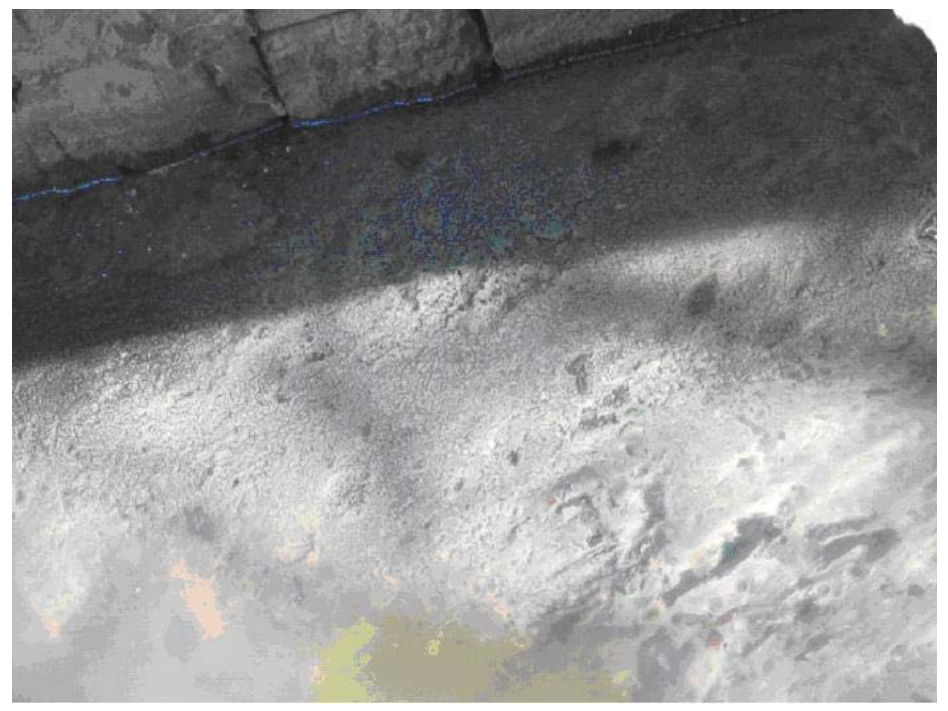

Figura 10 - Resíduos químicos na confluência do Arroio dos Pereiras com o rio das Antas

A retilinização do rio ocorrida em vários pontos da área urbana, procurando acomodar melhor a estrutura social e econômica existente, está proporcionando a ocorrência de processos geomorfológicos que modificam a dinâmica fluvial natural e o principal testemunho desta ocorrência é o assoreamento das margens (Figura 07) e a formação de ilhas fluviais (Figura 08).

Apesar de que os engenheiros sanitaristas não consideram a presença de algas, por si só, padrão significativo de alteração na qualidade de água, o acúmulo de tais espécies vegetais são bioindicadores de que algo não está equilibrado no sistema, ou pelo menos existe algum tipo de ocorrência dando incentivo à proliferação destas algas. Mesmo considerando a 


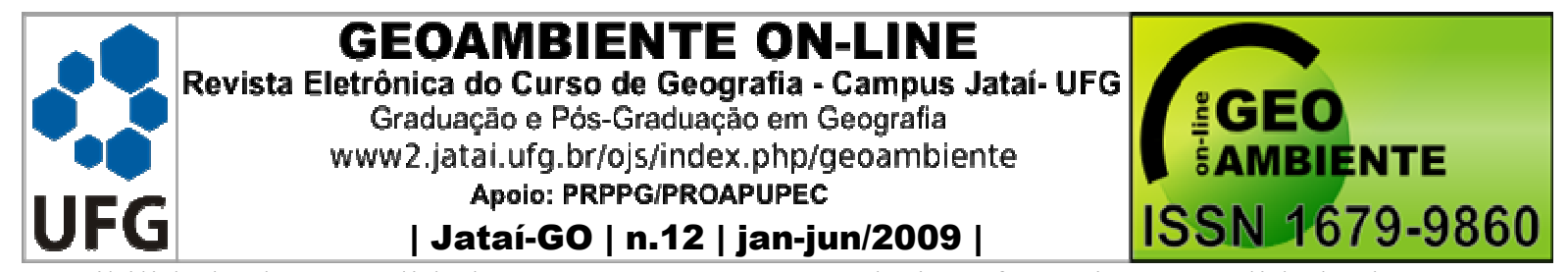

possibilidade desta realidade não estar representando interferência na qualidade da água, sua existência levantou a hipótese de estar ocorrendo algum tipo de degradação que estaria causando a eutrofização do rio.

O lixo urbano ou resíduos sólidos, não tem interferido significativamente no processo de degradação da bacia do rio das Antas, pois a quantidade de resíduos encontrados não é suficiente para causar significativo impacto negativo no rio, mas sua existência é inconteste, como mostram as Figuras 09 e 10. A primeira demonstra a ocorrência de bioindicadores (algas) que comprovam um excedente de resíduos, provocando dificuldades na capacidade de oxigenação da água. Na segunda figura, nota-se o acúmulo de material químico depositado no corpo do rio sem nenhum tratamento prévio, provocando impactos que afetam não só a qualidade da água, mas também a sobrevivência da fauna e flora local. Tais impactos podem ser mitigados por programas de sensibilização da população e com o projeto de reciclagem implementado pela atual administração, sem muito ônus à prefeitura.

O problema da erosão e conseqüente assoreamento, tornam-se um pouco mais difíceis de serem solucionados, visto que há dificuldade por parte da população ribeirinha em assimilar a idéia de que um ambiente limpo não signifique ausência de vegetação, o que já é um costume freqüente (limpar a propriedade, cortando o mato e retirando a vegetação, a fim de não juntar "bichos"). Também não se cogitam desapropriação das residências por duas questões: o alto custo a ser arcado pelo poder público e o apego ao local, por parte dos cidadãos que aí tem suas residências. Tais informações foram obtidos através de reuniões com o Conselho Municipal de Meio Ambiente, que ocorreram nos anos de 2005 e 2006.

A sedimentação tem relação direta com a interferência no meio natural, pela falta de mata ciliar causando erosão das margens e sendo agravada pela retilinização do canal fluvial. A impermeabilização do solo carreando sedimentos provenientes das vertentes desprovidas de vegetação, aumenta a velocidade do escoamento superficial desagregando os sedimentos do solo com mais facilidade.

Todos essas características inapropriadas foram notadas no decorrer do estudo, mas sua mitigação está em curso, principalmente através de programas de educação ambiental que estão sendo implementados pela administração municipal. 


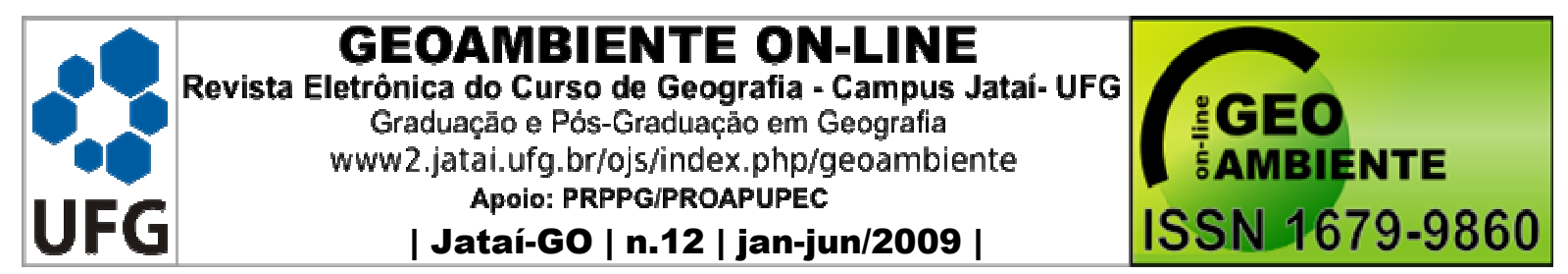

Contudo, o esgoto urbano é a principal fonte impactante na qualidade da água do rio das Antas, como já citado anteriormente, pois a poluição ocorrida através do despejo de efluentes e não somente resíduos sólidos, foi constatada através de análise da qualidade água.

A análise do problema ambiental, focada na qualidade da água do rio das Antas, não somente com os aspectos visuais o que leva a um diagnóstico superficial, mas também com a coleta de amostras de água do rio em cinco pontos demonstraram a má qualidade da água do rio. Os critérios utilizados na escolha dos pontos de coleta levaram em conta os principais tributários, visando analisar a contribuição dos mesmos na caracterização das amostras, além da menor ou maior concentração de atividades urbanas. Os resultados obtidos estão descritos na Tabela 01.

Tabela 01 - Análise de Água rio das Antas (Sanepar - Guarapuava)

\begin{tabular}{ccccc}
\hline Amostra & Turbidez (UNT) & $\mathrm{pH}$ & Coliformes Totais (UFC) & Coliformes Fecais (UFC) \\
\hline 1 & 42,7 & 6,8 & 13.000 & 9.200 \\
2 & 49,2 & 6,9 & $(* *)$ & 12.000 \\
3 & 54,6 & 6,9 & $(* *)$ & $(* *)$ \\
4 & 54,9 & 6,9 & $(* *)$ & 24.000 \\
5 & 60,2 & 6,8 & $(* *)$ & 24.000 \\
\hline
\end{tabular}

Obs.: $\quad$ UNT $=$ Unidade Nefelométrica de Turbidez;

$\mathrm{UFC}=$ Unidade formadora de colônias;

$(* *)=$ Contagem prejudicada pelo crescimento confluente de bactérias.

As amostras para as análises bacteriológicas foram diluídas na proporção $2 \mathrm{ml}$ da amostra para $98 \mathrm{ml}$ de água de diluição.

A Tabela 01 apresenta resultados da análise da qualidade da água realizada pela Companhia de Saneamento do Paraná - Sanepar (escritório de Guarapuava), a pedido dos autores. As variáveis que foram possíveis de serem investigadas com o método de análise disponível, foram: Turbidez; pH; Coliformes Totais; e Coliformes Fecais.

Com referência ao padrão de Turbidez ressalta-se que as principais causas da turbidez da água são: presença de matérias sólidas em suspensão (silte, argila, sílica, coloides), matéria orgânica e inorgânica finamente divididas, organismos microscópicos e algas. A origem desses materiais pode ser o solo (quando não há mata ciliar); a mineração (como a retirada de areia ou a exploração de argila); as indústrias; ou o esgoto doméstico, lançado no manancial sem tratamento.

As águas de lagos, lagoas, açudes e represas apresentam, em geral, baixa turbidez, porém variável em função dos ventos e das ondas que, nas rasas, podem revolver os sedimentos do fundo. Via de regra, após uma chuva forte, as águas dos mananciais de 


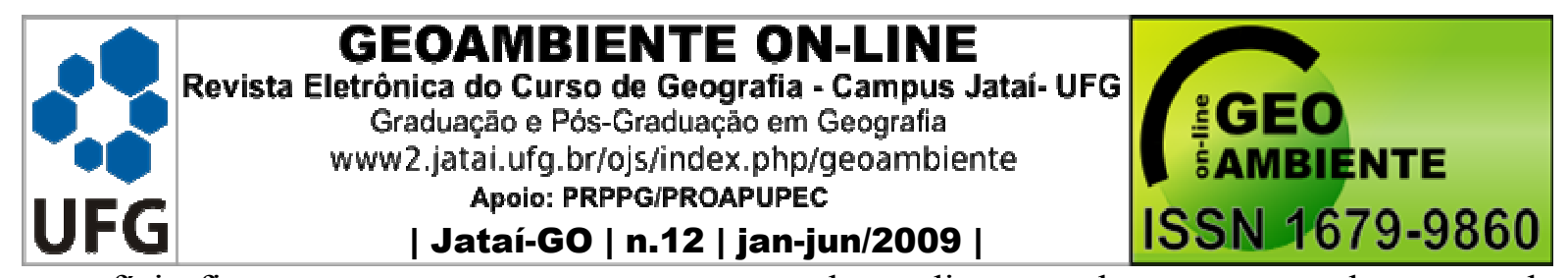

superfície ficam turvas, graças ao carreamento dos sedimentos das margens pela enxurrada. Assim, os solos argilosos e as águas em movimentação, ocasionam turbidez.

Considerando que as coletas foram feitas em um período chuvoso, inclusive no dia da coleta estavam ocorrendo pancadas de chuvas, esta variável não foi considerada significativa para a presente avaliação, mesmo porque apesar dos valores de referência estarem bastante elevados, ainda não são considerados totalmente inapropriados para alguns fins, até mesmo para o consumo humano, desde que devidamente tratada.

Os valores de $\mathrm{pH}$ também estão dentro de uma faixa considerada normal, inclusive com pouca variação entre os pontos de coleta, resultado que propicia a conclusão de que não existe nenhum fator externo propiciando alteração no $\mathrm{pH}$ da água no decorrer do rio. Nada indica alteração significativa na acidez da água, independente do rio estar em área rural ou urbana.

Com referência à quantidade de coliformes totais, infelizmente os resultados não dão margem a interpretações. Apesar da quantidade encontrada no ponto 1 ser bastante elevada (13000 UFC), a ocorrência do crescimento de bactérias prejudicou a contagem das outras amostras, o que por si só, já indica uma alteração na qualidade natural da água, mas que não define a existência de organismos originados de atividades urbanas.

Contudo, as amostras ressaltam uma quantidade muito grande de coliformes fecais nos pontos de coleta, o que comprova o nível de contaminação da água, sendo que o principal indicador de poluição é a presença de bactérias do grupo coliformes fecais, pois a quantidade máxima permitida é de 1.000 UFC por amostra. Todas as amostras apresentaram níveis altíssimos de coliformes fecais, com exceção do ponto 3 que teve sua contagem prejudicada. Nota-se claramente que a quantidade de coliformes é maior quanto mais a jusante do rio se localiza o ponto de coleta, demonstrando claramente que as atividades urbanas estão influenciando o aumento deste indicador de degradação ambiental.

Este resultado mostra o principal problema ambiental que ocorre no rio das Antas, que é o despejo de esgoto doméstico sem tratamento, e isso ocorre por falta de saneamento básico, ligações incorretas de esgoto e falta de fiscalização por parte dos órgãos competentes. Tal realidade ocorre desde sua nascente (ponto 1) e é intensificada na sua foz (ponto 5), através do acúmulo deste material. 


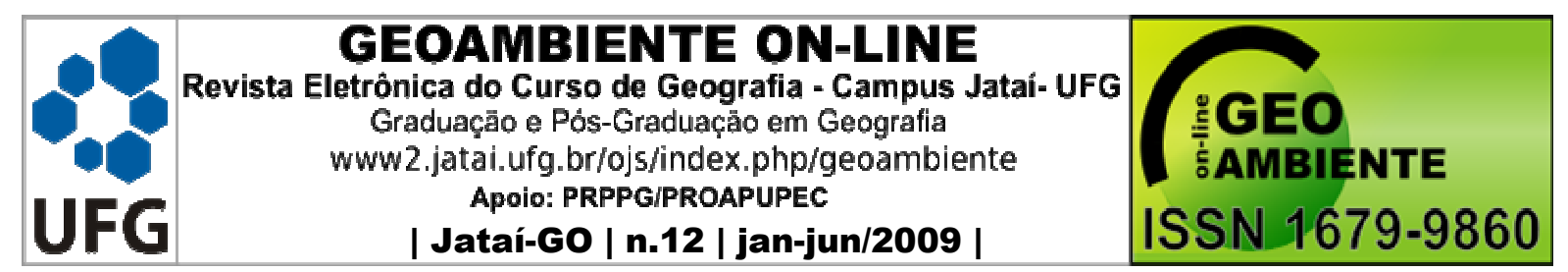

A poluição ocasionada pelo despejo de esgoto urbano acaba ocasionando a eutrofização do corpo hídrico, causando o desaparecimento da biota aquática e proliferação de agentes patológicos, realidade comprovada através dos trabalhos de investigação de campo. A ocorrência de algas (Figura 9) e material químico (Figura 10), combinada com os resultados da tabela 01 demonstram que fatores externos à dinâmica natural do rio, estão degradando (poluindo) suas águas.

\section{Conclusões}

Pode-se constatar uma série de fatores que contribuem para a degradação do ambiente aquático do rio das Antas, além dos problemas sanitários para a população ribeirinha. Alguns dos problemas encontrados, foram constatados através de visitas à área de estudo e são representados pelos seguintes fatores:

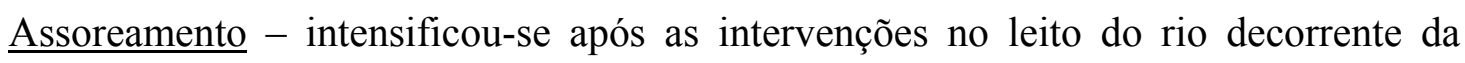
retilinização de vários trechos, aumentando a velocidade do carreamento de sedimentos das margens e do próprio canal, levando a ocorrência de ilhas sedimentares e o próprio assoreamento do canal fluvial, diminuindo assim o nível de água escoado, culminando com o aumento da concentração de resíduos orgânicos; e Esgoto Doméstico - foi onde se constatou a maior interferência no ambiente. Existem vários pontos do rio onde os efluentes domésticos são lançados in natura, diretamente no corpo hídrico. Apesar destes pontos não terem sido mapeados, pois são vários, os relatos de funcionários da SANEPAR (Companhia de Saneamento do Paraná) são de que existem pontos onde ocorre extravasamento de esgoto doméstico, devido ao cruzamento da rede de esgoto com a pluvial, e da rede pluvial com a de esgoto, além de esgoto doméstico ligado incorretamente na rede pluvial. Dessa forma, o problema é complexo e o primeiro passo seria fazer a identificação sistematizada destes pontos e tentar sanear este problema.

No caso específico do lançamento de esgoto in natura no rio das Antas, uma simples campanha de conscientização aliada a uma readequação das instalações de esgoto e galerias pluviais e fluviais, poderia resolver o problema, pois diminuiria a quantidade de resíduos depositados diretamente no corpo hídrico, sem o devido tratamento. O poder público poderia efetuar um monitoramento mais enérgico da qualidade dos recursos naturais do rio (fauna, flora e qualidade da água). 


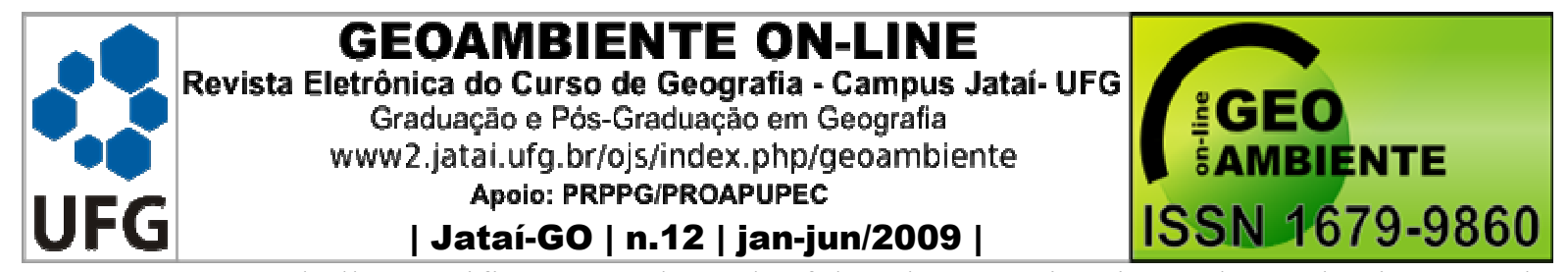

Neste trabalho verificou-se, além da falta de consciência e desconhecimento das conseqüências por parte da população, a pouca preocupação da Prefeitura Municipal com o saneamento, pois a péssima qualidade das águas do rio das Antas acarreta custos elevados em outras áreas, como saúde pública (devido à proliferação de vetores patogênicos em águas poluídas); na gestão de obras públicas (a fim de mitigar problemas decorrentes de enchentes devido a obras realizadas sem estudos mais apurados sobre a dinâmica da bacia); gastos com a captação de água (onde se tem que utilizar o rio Imbituvão no município de Fernandes Pinheiro, por não se encontrar corpos hídricos com água de boa qualidade no município de Irati). Tais conseqüências não foram diretamente investigadas e relacionadas, mas são problemas que podem ocorrer em virtude da falta de monitoramento das degradações ambientais ocorridas nas margens do principal rio urbano de Irati.

A interferência indevida no curso do rio (retilinização) está provocando alterações na dinâmica fluvial (diminuição da velocidade do fluxo e formação de ilhas fluviais). Isto foi notado através das observações de campo, apesar de não ter sido quantificado. Por isso, tal intervenção deveria ser melhor planejada e, se possível, evitada.

Mas, é na questão da poluição das águas através da ocorrência de coliformes fecais em números muitíssimo elevados, que o presente trabalho demonstra uma conclusão inconteste: a água do rio dos Antas está imprópria para qualquer consumo, atém mesmo o de animais domésticos. Tal ocorrência é creditada ao despejo de esgoto doméstico sem tratamento adequado, diretamente no curso d'água.

Estes são fatores onde se propõe um maior envolvimento do poder político nas questões ambientais, na elaboração de políticas públicas voltadas para a conservação dos recursos naturais, saneamento básico, na contratação de profissionais capacitados para trabalhar na área de planejamento urbano e elaboração de um plano diretor consistente, bem como, a construção de um programa de educação ambiental a longo prazo, buscando sensibilizar a população quanto à importância da conservação do ambiente.

Contudo, a principal providência a ser tomada, é a localização dos pontos de descarga de efluentes in natura e a solução deste problema, bem como, o redimensionamento das redes de esgoto doméstico e verificação dos pontos onde ocorrem os cruzamentos das redes pluviais com as de esgoto. 


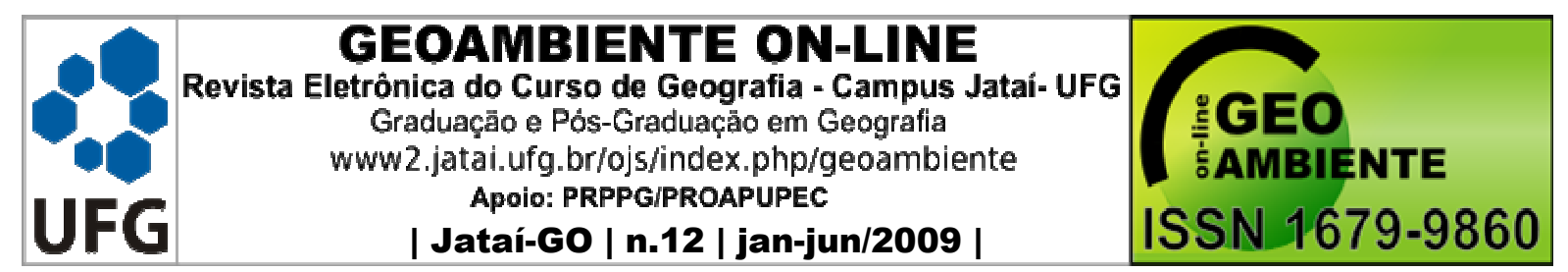

\section{Referências Bibliográficas}

ABNT - Associação Brasileira de Normas Técnicas (NBR 10.004). Resíduos Sólidos Classificação. Rio de Janeiro, Brasil, 63 pp. 2004.

ARAÚJO, L. A. Danos ambientais na cidade do Rio de Janeiro. IN: GUERRA, A. J. T. \& CUNHA, S. B. (orgs.). Impactos ambientais urbanos no Brasil. Rio de Janeiro: Bertrand do Brasil, 2006. p. 347-403.

BRANCO, S. M. Água: origem, uso e preservação, São Paulo: Moderna, 1993.

CLAVAL, Paul. A revolução pós-funcionalista e as concepções atuais da geografia. In: MENDONÇA, F.; KOZEL, S. (orgs.). Elementos de Epistemologia da Geografia Contemporânea. Curitiba: Editora da UFPR, 2002. p. 11-46

DREW, D. Processos interativos homem - meio ambiente, Rio de Janeiro: Bertrand Brasil, 2002 .

FENDRICH, R.; OLIYNIK, R. Manual de Utilização das Águas Pluviais. $1^{\text {a }}$ Edição. Curitiba: Livraria do Chain Editora. 190p., 2002.

GERARDI, Lucia Helena Oliveira; LOMBARDO, Magda Adelaide (orgs.). Sociedade e Nagtureza na visão da Geografia. Rio Claro: Programa de Pós-graduação em Geografia UNESP; Associação de Geografia Teorética - AGETEO, 2004, 296p.

GUERRA, A. J. T.; CUNHA, S. B. (org). Avaliação e perícia ambiental. 2. ed. Rio de Janeiro: Bertrand Brasil, 2000.

GUERRA, A. J. T. \& CUNHA, S. B. (orgs.). Impactos ambientais urbanos no Brasil. Rio de Janeiro: Bertrand do Brasil, 2006. 416p.

IPARDES (Paraná). Cadernos Municipais Ipardes. Disponível em: $<$ http://www.ipardes.gov.br/cadernos/Montapdf.php?Municipio $=84500 \& b t O k=o k>$. Acesso em: 19 set. 2006.

MINEROPAR - Minerais do Paraná S/A. Disponível em: <http://www.mineropar.pr.gov.br>. Acesso em: 19 set. 2006.

MONTEIRO, J. H. P. et al. Manual de gerenciamento integrado de resíduos sólidos. Rio de Janeiro: IBAM, 2001.

ORREDA, J. M. Irati I. Irati: Edipar, 1972. . Irati II. Irati: Edipar, 1974.

PUPPI, I. C. Estruturação sanitária das cidades. São Paulo: CETESB, 1981. 


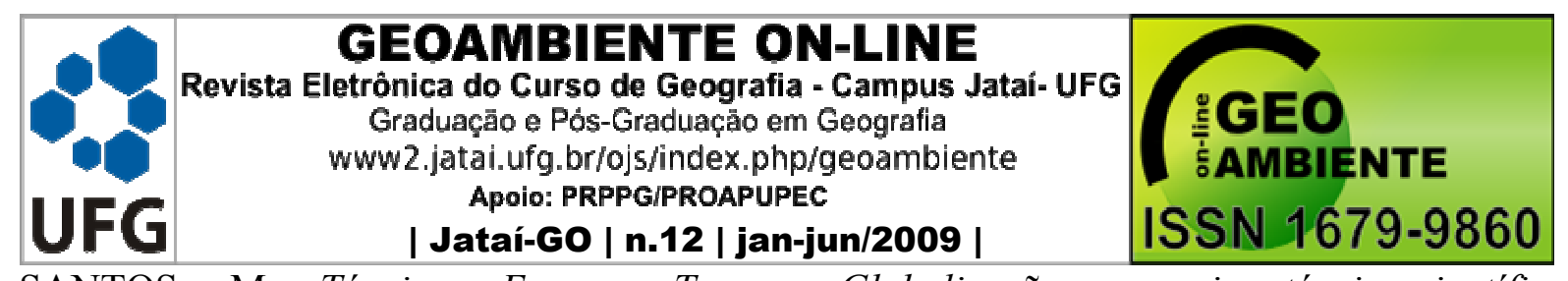

SANTOS, M. Técnica, Espaço, Tempo: Globalização e meio técnico-científico informacional. São Paulo: Hucitec, 1994.

SOUZA, M. L. Algumas Notas sobre a Importância do Espaço para o Desenvolvimento Social. In: Território 3, LAGET/UFRJ, Garamond, pp. 13-35. 